\title{
Analisis Kehidupan Sosial Ekonomi Pengemis dan Penanggulangannya di Kota Banda Aceh
}

\author{
Ulfia $^{* 1}$, Rahmi $^{1}$ \\ ${ }^{1}$ Program Studi Akuntansi, Fakultas Ekonomi, Universitas Serambi Mekkah, Banda Aceh, 23249, \\ Indonesia \\ *Email korespondensi: ulfia@serambimekkah.ac.id ${ }^{1}$
}

Diterima 21 September 2018; Disetujui 15 Oktober 2018; Dipublikasi 31 Oktober 2018

\begin{abstract}
This study aims to find out how the socio-economic life of beggars in Banda Aceh and the government's efforts to overcome the problem of beggars in Banda Aceh. This is a descriptive study with a qualitative approach with a sample of 35 beggars. This study used interview in the form of questionnaire surveys and observations field as well as some data from related agencies. The results of the tabulation are illustrated to understand the data obtained from the respondents and the percentage of data analysis. The results showed that the cause of these people became beggars due to several factors that occurred in their lives. The Government has made various efforts to tackle beggars through the Social Service of Banda Aceh in collaboration with the community to eradicate beggars. Efforts that have been made by the Government of Banda Aceh for the prevention of beggars are preventive efforts, coercive efforts, rehabilitation efforts, and social reintegration efforts to prevent the appearance of more beggars. Besides, the efforts to prevent the spread of the effect of begging in the community, the government appeals to the community not to give money and goods to beggars, but they should give them to the social institutions in accordance with the legislation set by the Government of Banda Aceh.
\end{abstract}

Keywords: beggars, socio-economic, prevention

\begin{abstract}
Abstrak: penelitian ini bertujuan untuk mengetahui bagaimana kehidupan sosial ekonomi pengemis dan upaya pemerintah dalam penanggulangannya di Kota Banda Aceh. Penelitian menggunakan pendekatan kualitatif dengan sampel sebanyak 35 orang pengemis. Penelitian ini menggunakan teknik wawancara dan observasi. Hasil penelitian menunjukkan bahwa penyebab para pengemis ini melakukan aksinya dengan mengemis karena beberapa faktor yang terjadi dalam kehidupannya, baik faktor eksternal maupun faktor internal. Sedangkan upaya pemerintah Kota Banda Aceh untuk penanggulangannya melalui Dinas Sosial Kota Banda Aceh bekerja sama dengan masyarakat untuk pemberantasan pengemis. Upaya-upaya yang telah dilakukan diantaranya berupa upaya preventif, upaya koersif, upaya rehabilitasi, dan upaya reintegrasi sosial untuk mencegah agar tidak terjadi lagi kegiatan mengemis ini. Dan upaya memberikan himbau kepada masyarakat untuk tidak memberikan uang atau sumbangan kepada para pengemis dan menyalurkannya kepada lembaga/badan sosial sesuai peraturan yang telah di tetapkan oleh Pemerintah Kota Banda Aceh.
\end{abstract}

Kata kunci : pengemis, sosial ekonomi, penanggulangan 
Indonesia merupakan negara yang mempunyai kekayaan alam yang sangat banyak dan berlimpah. Dengan letak geografis yang strategis diapit oleh dua benua dan dua samudra, serta banyaknya barang tambang yang terdapat di dalamnya. Banyaknya faktor yang menimbulkan terciptanya sumber daya manusia yang kurang relevan dalam mengolah kekayaan yang telah ada, baik itu dari faktor individu yang kurang meningkatkan tingkat pengetahuan dalam wawasan atau dari pihak pemerintah dalam memaksimalkan program pendidikan dalam mengurangi angka buta huruf.

Setiap negara mempunyai langkah maju untuk membawa masyarakatnya dalam meningkatkan kesejahteraan dan kemakmuran dalam negara tersebut, salah satunya dengan meningkatkan sektor pembangunan. Dan dapat diwujudkan melalui proses peningkatan pemerataan pembangunan dalam negara dan hasil-hasil pencapaiannya yang merujuk kepada terciptanya keadilan sosial bagi seluruh rakyat, mencapai pertumbuhan ekonomi yang cukup tinggi serta menciptakan stabilitas nasional yang mantap dan dinamis.

Proses pembangunan yang berlangsung selama ini diantaranya terwujudnya ketimpangan atau ketidaksetaraan dalam dimensi ekonomi. Banyak kelompok masyarakat yang mengalami perbaikan dan meningkatnya taraf hidup mereka. Namun, pada sisi lain masih terdapat kelompok masyarakat yang berada pada kehidupan yang memprihatinkan.

Sama halnya dengan negara berkembang lainnya, Indonesia juga mengalami banyak permasalahan dibidang kependudukan. Diantaranya, tingginya tingkat kelahiran per tahunnya, kemiskinan yang terus meningkat dalam masyarakat, jumlah pengangguran setiap tahunnya, bahkan rendahnya tingkat pendidikan para penduduk, pelayanan kesehatan yang tidak semua bisa di dapat oleh masyarakat, dan rendahnya produktivitas oleh masyarakat pekerja.

Tingginya tingkat kelahiran menyebabkan semakin tingginya tingkat pertumbuhan penduduk dalam suatu negara yang kedepannya akan berdampak pada sektor ketenagakerjaan. Hal ini menggambarkan bahwa akan banyaknya tenaga kerja dimasa yang akan datang dan berbanding terbalik dengan penciptaan lapangan kerja berjalan lebih lambat daripadanya, sehingga menimbulkan pengangguran.

Pengangguran-pengangguran ini tersebar di berbagai daerah, yaitu di daerah-daerah perkotaan maupun di daerah pedesaaan. Pengangguran yang sering terjadi ini biasanya pengangguran terselubung (tersembunyi) yaitu golongan tenaga kerja yang produktivitas marjinalnya adalah nol atau sangat rendah, sehingga walaupun bekerja tetap tidak akan menaikkan tingkat produksi dan pengangguran musiman yaitu pengangguran yang terjadi pada masa-masa tertentu, seperti kegiatan pertanian dimana pada bulan-bulan tertentu atau kegiatan produksi lainnya lebih sedikit dilakukan di bandingkan dengan masa-masa lainnya. (Sukirno, 2013)

Pengangguran merupakan masalah yang rumit dalam setiap negara berkembang. Jika tingkat pengangguran tinggi, maka sumber daya yang ada akan terbuang percuma dan untuk tingkat pendapatan masyarakatnya pun akan menurun. Akibat lain dari pengangguran adalah meningkatnya angka kejahatan atau kriminalitas yang tinggi di 
dalam kehidupan bermasyarakat, kenakalan remaja yang berujung pada penggunaan obat-obatan terlarang, dan juga akan berdampak pada tingginya angka kemiskinan yang secara tidak langsung menghambat pelaksanaan program pembangunan.

Kemiskinan juga merupakan masalah yang timbul akibat perkembangan sosial, budaya, politik, dan ekonomi. Masyarakat yang tidak mempunyai daya saing yang kuat dalam menghadapi kehidupan maka mereka hanya akan menjadi penonton atau menjadi tenaga kerja di tingkat bawah dan kalah bersaing dengan tenaga kerja lainnya, yang pada akhirnya akan terpuruk di dalam kemiskinan. Masalah kemiskinan juga menjadi hal yang serius di Provinsi Aceh, akibatnya banyak masyarakat yang menghalalkan segala cara untuk mendapatkan pendapatan guna memenuhi kebutuhannya.

Menurut Badan Pusat Statistik (2015) standar masayarakat miskin rata-rata itu pengeluarannya berada di bawah Garis Kemiskinan Makanan (GKM). Standar ini dihitung dari pengeluaran minimum makanan yaitu sebanyak 2100 kkalori per hari.

Masalah kemiskinan juga berkaitan erat dengan tingkat pendidikan seseorang. Ketika seseorang mengalami kemiskinan maka pendidikan akan sulit di dapat. Sehingga hubungan antara kemiskinan dengan kebodohan sangat erat kaitannya (Winardi, 2010). Untuk melihat tinggi rendahnya pendidikan suatu daerah dapat dilihat dari tinggi rendahnya angka melek hurup atau besarnya alokasi dana suatu daerah untuk pendidikan.

Akibat dari kemiskinan tersebut timbul kesenjangan sosial ekonomi dalam masyarakat, salah satu contohnya adalah semakin banyaknya jumlah pengemis. Tidak terkecuali di tingkat kabupaten, pada Kota Banda Aceh tingkat pengemis juga bertambah. Hal ini salah satunya disebabkan karena merupakan ibukota provinsi sehingga banyak warga yang datang untuk mengadu nasib di kota ini.

\section{TINJAUAN PUSTAKA}

\section{Pengemis}

Umumnya di kota besar sering terlihat pengemis meminta uang, makanan, atau benda lainnya. Beberapa tahun lalu, menjadi seorang pengemis merupakan suatu keadaan yang terpaksa dan dilakukan dengan malu, akan tetapi saat ini merupakan hal yag dilakukan dengan sukarela. Profesi sebagai seorang pengemis ini memiliki daya tarik tersendiri bagi para pengemis tersebut, sehingga menimbulkan persaingan di antara sesama mereka. Dampak yang di dapat dari persaingan ini salah satunya adalah timbulnya coordinator dalam pelaksanaan kegiatan ini, yang bertugas mengatur jumlah pengemis yang beroperasi di beberapa titik lokasi dan sekaligus mencari daerah baru untuk melancarkan aksinya.

Ciri-ciri pengemis diantaranya adalah (Dinas Sosial, 2015):

a. Meminta-minta ada yang di rumah penduduk, ke toko-toko, mangkal di persimpangan lalu lintas, di pasar-pasar tradisional, tempat ibadah yang dekat dengan pusat kota dan tempat umum lainnya.

b. Pada umumnya mereka melakukan aksinya dengan berpura-pura sakit, merintih dan bahkan ada yang kadang-kadang mendoakan dengan bacaan ayat-ayat suci, mengatas namakan yayasan, anak yatim, hingga organisasi tertentu.

c. Pelaku dari yang berusia anak hingga yang berusia dewasa (laki-laki atau perempuan). 
Masalah pengemis terjadi di hampir setiap negara. Menurut Soejono Soekanto hal ini disebabkan karena ketidaksesuaian unsur-unsur kebudayaan dalam tatanan negara. Beliau juga membedakan masalah sosial menjadi empat, yaitu sebagai berikut (Maryadi, 2016):

a. Masalah pada faktor ekonomi, seperti kemiskinan dan pengangguran

b. Masalah pada faktor biologis, seperti penyakit menular

c. Masalah pada faktor psikologi, seperti syarat dan bunuh diri

d. Masalah pada kebudayaan, seperti perceraian dan kenakalan remaja.

\section{Teori Kemiskinan}

Menurut Winardi (2010) dalam bukunya menjelaskan bahwa kemiskinan memiliki dua dimensi yaitu dimensi pendapatan dan dimensi non pendapatan. Kemiskinan dalam hal pendapatan yaitu kemiskinan yang di sebabkan rendahnya pendapatan yang diterima oleh para pekerja, sedangkan non pendapatan yaitu ketidakmampuan, tidak memiliki harapan, dan tidak memiliki kebebabasan. Kemiskinan dari segi pendapatan lebih mudah di hitung sehingga menjadi kemiskinan relatif dan kemiskinan absolut.Sedangkan penduduk miskin yaitu masyarakat yang rata-rata pengeluaran per kapita per bulan dibawah garis kemiskinan yang telah di tetapkan.

Ada tiga kategori kemiskinan yang menjadi pusat perhatian Dinas Sosial (2001) yaitu:

1. Kelompok yang paling miskin (destitute) atau fakir miskin. Dimana mereka tidak memiliki sumber pendapatan sama sekali bahkan mereka tidak punya akses terhadap berbagai pelayanan sosial.

2. Kelompok miskin (poor). Kelompok ini mempunyai pendapatan akan tetapi berada dibawah garis kemiskinan namun masih bisa mendapatkan pelayanan sosial dasar (misalnya, masih memiliki sumber-sumber finansial, memiliki pendidikan dasar atau buta huruf).

3. Kelompok renta (velnerable group). Kelompok ini bebas dari kemiskinan atau hidupnya relatif lebih baik. Akan tetapi masyarakat ini sangat renta terhadap berbagai perubahan social yang akan terjadi. Mereka bisa saja berubah dari posisi lebih baik menjadi miskin atau bahkan sampai sangat miskin jika tidak mendapat pertolongan sosial.

Berikut ini beberapa faktor yang menggambarkan tinggi rendahnya keadaan sosial ekonomi seseorang dalam masyarakat (Wirutomo, 2012) yaitu:

a. Tingkat Pendidikan

b. Jenis Pekerjaan

c. Tingkat pendapatan

d. Keadaan Rumah Tangga

e. Tempat Tinggal

f. Kepemilikan Kekayaan

g. Jabatan dalam Organisasi

h. Aktivitas Ekonomi

\section{Teori Pendapatan}

Pendapatan yang diperoleh oleh setiap individu biasanya berupa uang sebagai hasil dari usahanya atau dari jasa-jasa produksi yang dilakukannya sesuai dengan keinginannya yang biasanya disebut sebagai pendapatan disposabel (disposable income). 
Pendapatan disposabel adalah sejumlah uang yang sesungguhnya diterima oleh masyarakat rumah tangga yang boleh dibelanjakan oleh penerimanya untuk membeli barang dan jasa sesuai dengan keinginannya (Samuelson, 2001).

Dalam setiap kegiatan perekonomian, individu pasti mengharapkan adanya suatu imbalan yang akan diterimanya atas hasil usaha yang telah dilakukannya dalam suatu periode. Imbalan ini disebut juga sebagai akibat dari adanya suatu kegiatan yang dikerjakan atau dilakukan oleh seorang individu pada suatu periode tertentu. Pendapatan dapat berupa pendapatan yang diterima atau imbalan jasa yang diperoleh bukan dari menawarkan faktor produksi yang disebut sebagai transfer payment seperti dana pensiun atau beasiswa. Transfer payment merupakan pendapatanpendapatan individu yang diperoleh tanpa menyediakan tenaganya untuk memperoleh pendapatan tersebut. (Sukirno, 2013).

Pendapatan konsumen sangat berpengaruh terhadap tingkah lakunya yang dicerminkan oleh permintaannya terhadap barang dan jasa. Apabila pendapatan bertambah, otomatis pendapatan yang dibelanjakan juga akan bertambah. Besarnya pengaruh kenaikan pendapatan terhadap permintaan barang dan jasa sangat ditentukan oleh besarnya elastisitas pendapatan. Semakin besar elastisitas pendapatan, maka semakin besar pengaruh perubahan pendapatan terhadap permintaan. (Nicholson, 2008)

\section{Teori Konsumsi}

Menurut Sukirno (2013) konsumsi merupakan pembelanjaan yang dilakukan oleh rumah tangga terhadap barang dan jasa dengan tujuan untuk memenuhi kebutuhan dari orang yang melakukan pekerjaan tersebut. Nilai pembelanjaan yang dilakukan oleh rumah tangga untuk membeli berbagai jenis kebutuhannya dalam suatu tahun tertentu, yang dinamakan dengan pengeluaran konsumsi rumah tangga atau dalam analisis makroekonomi disebut konsumsi rumah tangga.

Kita asumsikan tingkat konsumsi tergantung secara langsung pada tingkat pendapatan disposibel. Semakin tinggi pendapatan disposibel, semakin besar konsumsi, jadi:

$$
\mathrm{C}=\mathrm{c}(\mathrm{Y}-\mathrm{T})
$$

Hal ini menyatakan bahwa konsumsi adalah fungsi dari pendapatan disposibel. Hubungan antara konsumsi dan pendapatan disposibel disebut fungsi konsumsi (consumption function). Marginal Propensity to Consume (MPC) adalah jumlah perubahan konsumsi ketika pendapatan disposibel meningkat sampai satu dolar. Naiknya pendapatan satu dolar akan meningkatkan konsumsi tapi peningkatannya akan kurang dari satu dolar, karena jika rumah tangga memperoleh pendapatan tambahan sebesar satu dolar mereka akan menabungkan sebagian pendapatan tambahannya tersebut.

\section{Faktor-faktor yang mempengaruhi konsumsi}
a. Kekayaan
b. Ekspektasi
c. Jumlah Penduduk
d. Tingkat Harga

\section{Pendidikan}

Menurut Todaro dan Smith (2006) menyatakan bahwa bidang ekonomi dan bidang pendidikan memiliki keterkaitan yang sangat kuat. Terlihat dari 
produktifitas kerja dengan output yang dihasilkan. Hal ini dikarenakan persoalan perekonomian adalah tingkat pertumbuhan output total yang dihasilkan oleh suatu negara. Selanjutnya Todaro juga menyatakan bahwa pendidikan merupakan tujuan yang paling berpengaruh dalam pembangunan suatu negara. hal ini merupakan kunci dalam membangun ekonomi dan memajukan sebuah bangsa, membantu manyerap teknologi, menciptakan pertumbuhan dan pembangunan berkelanjutan.

Masalah yang ditimbulkan oleh kurangnya pendidikan ini salah satunya yaitu melahirkan banyaknya orang yang meminta-minta atau orang yang menjadi pengemis. Di Indonesia buka hal yang baru, akibat keterdesakan ekonomi menyebabkan banyak anak dan kaum dewasa terlibat dalam hal mengemis meskipun dengan cara dan teknik yang berbeda. Hal ini bisa kita lihat hampir di setiap kota di Indonesia mempunyai pengemis dan ini bukan merupakan hal yang membanggakan akan tetapi ini merupakan hal yang sangat miris dalam kehidupan negara kita.

\section{METODE PENELITIAN}

Penelitian ini dilakukan di Kota Banda Aceh. Populasi dalam penelitian adalah seluruh masyarakat yang berdomisili di Kecamatan Baiturrahman, Meuraxa, Syiah Kuala, dan Kuta Raja. Menurut data dari BPS penduduk yang menjadi pengemis berada di 3 kecamatan tersebut. Untuk sampel yang diteliti pada penelitian ini yaitu sebanyak 35 orang. Dalam penelitian ini teknik pengambilan sampelnya menggunakan cara Sampling Probability.

\section{HASIL DAN PEMBAHASAN}

\section{Gambaran Umum Kota Banda Aceh}

Kota Banda Aceh dengan luas $61.36 \mathrm{~km}^{2}$ ini berpenduduk 254.904 jiwa. Mereka tersebar di sembilan kecamatan yaitu: (1) Meuraxa, (2) Jaya Baru, (3) Banda Raya, (4) Baiturrahman, (5) Lueng Bata, (6) Kuta Alam, (7) Kuta Raja, (8) Syiah Kuala, dan (9) Ulee Kareng dan kecamatan baru, yaitu: (10) Darul Imarah. Batas Kota Banda Aceh dengan wilayah disekitranya, di bagian utara berbatasan dengan Selat Malaka, sebelah selatan dan timur berbatasan dengan Kabupaten Aceh Besar, dan pada bagian barat berbatasan dengan Samudra Hindia (BPS Banda Aceh, 2017).

Permasalahan kesejahteraan sosial dan sumber daya kesejahteraan sosial, data Dinas Sosial Banda Aceh tahun 2016 menunjukkan sebagai berikut:
1. Fakir Miskin
$: 26.807$
2. Lanjut Usia Terlantar
3. Penyandang Disabilitas $: 468$
4. Rumah Tangga Layak Huni $: 166$
5. Yatim, Piatu,Yatim-piatu $: 2.057$
6. Perempuan Rawan Sosial Ekonomi
:932

Data penelitian yang di peroleh dari Dinas Sosial Kota Banda Aceh terdapat beberapa kecamatan yang menjadi tempat tinggal para pengemis diantaranya di Kecamatan Baiturrahman yaitu sebanyak 4 orang, pada Kecamatan Meuraxa sebanyak 2 orang, pada Kecamatan Syiah Kuala sebanyak 3 orang, dan yang paling banyak berada di daerah Kecamatan Kuta Raja yaitu sebanyak 38 orang. Hal ini menjawab bahwa para pengemis ini memilih Kuta Raja sebagai tempat untuk tinggal karena pada kecamatan ini merupakan daerah yang 
sentral dan memiliki akses cukup dekat dengan pusat kegiatan masyarakat seperti pasar, toko-toko, Masjid Raya Baiturrahman, dan beberapa akses masyarakat lainnya.

Menurut hasil wawancara dengan para pengemis sebanyak 30 orang, yang berasal dari Kota Banda Aceh hanya beberapa orang saja yaitu sebanyak 3 orang. Sedangkan yang berasal dari luar Kota Banda Aceh paling banyak berasal dari Aceh Besar yaitu sebanyak 8 orang, dan dari beberapa daerah lainnya seperti Pidie, Aceh Utara, Aceh Timur, Bireuen, Takengon, Nagan Raya, Aceh Selatan dan Aceh Barat. Banyak nya pengemis di Kota Banda Aceh yang tidak berdomisili di Kota banda aceh menjelaskan bahwa Banda Aceh menjadi kota yang paling di incar oleh para pengemis untun mencari rejeki dengan jumlah penduduk yang banyak serta ibu kota Provinsi Aceh.

Berdasarkan data yang berhasil dikumpulkan di lapangan mengenai jumlah pendapatan pengemis, ternyata tingkat pendapatan yang di peroleh sangat bervariasi. Mulai dari tingkat yang paling rendah yaitu kurang dari Rp. 40.000 hingga pendapatan yang paling tinggi yaitu $>$ Rp. 100.000 yang dihitung perhari kerja.

Pada dasarnya pendapatan pengemis ini tidak dapat memenuhi kebutuhan hidup mereka tetapi karena terpaksa dan tidak memiliki pekerjaan lainnya, maka hal ini terus dilakukan baik karena cacat atau tidak adanya modal untuk membuka usaha. Setelah dilakukan wawancara dan pengamatan dengan para pengemis ini di dapatkan beberapa informasi yang menjelaskan bahwa profesi ini sangat menjanjikan untuk terus melakukan aksinya sehingga perlu upaya yang lebih tegas dari pemerintah sehingga tidak lagi bertambah para pengemis tersebut.

Berdasarka data dari lapangan yang telah di dapat, konsumsi para pengemis juga bervariasi. Mulai dari kurang dari Rp. 20.000 sampai lebih dari Rp. 50.000. Hal ini disebabkan karena sebagian besar pengemis sudah menikah, jadi penghasilan yang didapat juga digunakan untuk memenuhi kebutuhan hidup keluarganya dan mereka yang memiliki tanggungan lebih banyak mengharuskan mereka bekerja lebih giat lagi sehingga cenderung para pengemis ini biasanya bekerja mulai pagi hingga sore. Hal ini dikarenakan tingkat konsumsi untuk kebutuhan di dapat dari hasil mengemis semua tanpa ada bantuan dari pihak lain atau kerja sampingan lainnya.

Berdasarkan data yang telah berhasil dikumpulkan di lapangan mengenai pendidikan para pengemis, ternyata tingkat pendidikan yang di tempuh beragam. Mulai dari yang tidak tamat Sekolah Dasar (SD) hingga yang paling tertinggi berhasil menyelesaikan Sekolah Menengah Atas (SMA). Kebanyakan dari para pengemis ini ketika di wawancara menyatakan kalau mereka tidak tau harus bekerja apa dengan tingkat pendidikan yang ada, sehingga mereka lebih memilih pekerjaan sebagai pengemis yang tidak menuntut tingkat pendidikan yang tinggi.

Berdasarkan hasil dari wawancara terhadap pengemis mereka menceritakan bahwa setelah mereka di razia atau tangkap oleh Satuan Polisi Pamong Praja (Satpol PP) dan di bawa ke rumah singgah. Sedangkan menurut hasil wawancara dengan pihak Dinas Sosial, setelah pengemis di razia mereka di bawa ke tempat penampungan guna dilakukan pembinaan rehabilitasi. Mereka akan diberikan beberapa bimbingan diantaranya 
bimbingan mental sosial dan bimbingan keterampilan kerja.

Lokasi para pengemis ini tak hanya yang berdiri di persimpangan jalan, emperan toko, bahkan ada dari beberapa pengemis ini menjadikan kantorkantor instalasi pemerintahan sebagai tempat mereka mencari rezeki. Pemerintahan Kota Banda Aceh melalui Dinas Sosial telah mengeluarkan seruan kepada masyarakat untuk tidak melayani gelandangan dan pengemis (gepeng) di tempat umum. Masyarakat diingatkan agar tidak memberikan fasilitas dan ruang aktivitas kepada pengemis di tempat-tempat kerja maupun tempat usaha yang bisa mengganggu kenyamanan pengunjung dan masyarakat pada umumnya. (Serambi, 2016).

Pemerintah Kota Banda Aceh mengambil sikap cara penanggulangan para pengemis ini yaitu dengan beberapa upaya yang bersifat sebagai berikut:

a. Upaya Preventif, yaitu dengan memberikan ketrampilan, pelayanan kesehatan, penyuluhan dan edukasi masyarakat, pemberian informasi melalui media cetak dan elektronik dan juga bimbingan sosial.

b. Upaya Koersif, yaitu dilakukan dengan: (1). Penertiban, seperti orang yang tinggal di tempat umum atau bahkan orang yang mengalami gangguan jiwa serta orang yang meminta-minta dengan mengatas namakan lembaga atau organisasi yang belum memiliki izin sesuai ketentuan, (2). Pembinaan spiritual, (3). Pembinaan di Rumah Singgah Sederhana (RSS), dan (4). Pelimpahan atau rujukan, dimana tidak sedikit pengemis, gelandangan dan tuna sosial lainnya yang tidak sedikit mereka berasal dari luar Kota Banda Aceh dan atau instansi yang terkait lainnya untuk penanganan lebih lanjut.

c. Upaya Rehabilitasi, yaitu upaya yang dilakukan melalui motivasi dan diagnose psikososial, penampungan sementara, bimbingan mental spiritual, bimbingan fisik, investigasi dan konseling psikososial, pelayanan aksesebilitas serta pelimpahan/rujukan.

d. Upaya Reintegrasi Sosial, yaitu upaya yang dilakukan melalui resosialisasi, koordinasi dengan pemerintah Kabupaten/Kota lain, pemulangan, dan pembinaan lanjutan bagi penduduk kota.

Terkait masalah penanggulanggannya dalam Peraturan Walikota Banda Aceh No. 7 Tahun 2018 juga menjelaskan larangan terhadap masyarakat untuk tidak melakukan aktivitas mengemis, menjadi gelandangan dan serta tuna sosial. Hal ini dapat dilihat pada Pasal 21 yang berbunyi:

Setiap orang dilarang:

1. Melakukan aktifitas menggelandang dan/atau mengemis baik perorangan atau berkelompok dengan alasan, cara dan alat apapun untuk menimbulkan belas kasihan orang lain.

2. Memperalat orang lain dengan mendatangkan seseorang/beberapa orang baik dari dalam daerah ataupun dari luar daerah untuk maksud melakukan aktifitas dan/atau mengemis.

3. Mengajak, membujik, membantu, menyuruh, memaksa, dan mengkoordinir orang lain secara perorangan atau berkelompok sehingga menyebabkan terjadinya gelandangan dan/atau mengemis. 
4. Memfasilitasi tempat tinggal bagi para pengemis/peminta-minta.

Pemerintah Kota Banda Aceh juga memasang pamplet pemberitahuan larangan tidak memberikan sumbangan dalam bentuk apapun kepada peminta-minta/pengemis. Hal ini seperti yang terdapat pada pasal 22 dalam Peraturan Walikota Banda Aceh, yaitu sebagai berikut:

1. Setiap orang/pelaku usaha/lembaga/badan hukum dilarang memberikan uang dan/atau barang dalam bentuk apapun kepada gelandangan dan pengemis di tempat umum.

2. Pemberian uang dan/atau barang sebagaimana dimaksud pada ayat (1) dapat disalurkan melalui lembaga/badan sosial sesuai peraturan perundnag-undangan.

\section{KESIMPULAN DAN SARAN}

\section{Kesimpulan}

1. Pada dasarnya tingkat pendapatan pengemis perharinya tidak dapat mencukupi kebutuhan hidup pengemis tersebut. Akan tetapi karena profesi ini di anggap paling gampang untuk mencari nafkah yang mana hanya bermodalkan belas kasihan orang lain sehingga terus menjanjikan pendapatan, maka para pengemis terus melakukan aksinya.

2. Sedikit banyaknya tingkat pendapatan akan mempengaruhi tingkat konsumsi bagi pengemis tersebut. Dengan jumlah pendapatan sedikit, konsumsi para pengemis juga kurang yang dapat mengurangi kesejahteraan pengemis. Menurut data lapangan tingkat konsumsi rata-rata pengemis tertinggi mengalami variasi.
3. Faktor yang menyebabkan pengemis tetap memilih profesi sebagai pengemis antara lain:

a. Penyandang cacat tubuh atau cacat lainnya.

b. Penduduk miskin

c. Tingkat penduduk dan ketrampilan yang rendah

d. Sulit mendapat pekerjaan yang sesuai dengan keahlian mereka

\section{Saran}

1. Untuk mengatasi pertumbuhan jumlah pengemis di Kota Banda Aceh khususnya dan di Aceh umumnya, maka perlu dipikirkan usaha-usaha yang dapat membuat pengemis tersebut merasa bahwa profesi yang dijalankannya selama ini adalah termasuk profesi yang kurang mulia.

2. Perlu adanya usaha-usaha pembinaan mental maupun ketrampilan tertentu bagi para pengemis agar mereka mau meninggalkan profesi ini dan beralih kepada profesi yang menguntungkan dilihat dari segi ekonomi.

3. Perlu adanya usaha-usaha yang berkesinambungan dalam usaha memperbaiki kehidupan rakyat di Aceh baik dalam bentuk pemberian modal maupun dalam bidang kehidupan sosial masyarakatnya.

\section{DAFTAR PUSTAKA}

Aziz Muslim. (2012). Dasar-dasar Pengembangan Masyarakat. Yogjakarta: Samudra Buru..

Badan Pusat Statistik. (2016). Indikator Sosial Ekonomi Provinsi Nanggroe Aceh Darussalam. kerjasama BPR dan Bappeda NAD 
Badan Pusat Statistik. (2015). Profil Kemiskinan di Provinsi Aceh, Maret 2015. No. 46/09/TH XVIII, 15 Sep 2015.

Hutomo, Mardi Yatmo. (2000). Pemberdayaan Masyarakat Dalam Bidang Ekonomi: Tinjauan Teoritis Dan Implementasi. Naskah No. 29 Juni-Juli.

Indonesia, Serambi. (2016). Banda Aceh Keluarkan Seruan tak Layani pengemis di tempat Umum. Edisi Senin, 29 agustus 2016. Tersedia pada http://aceh.tribunnews.com.

Maryati, Kun, Juju Suryawati. (2016). Sosiologi. Jakarta: Erlangga.

Maulida, Oktaviana.,dkk. (2014). Pengemis dan Upaya Penanggulangannya (Studi Kasus di Desa Rarang Tengah Kecamatan Terara Kabupaten Lombok Timur). Vol: 4 No. 1 Tahun 2014. Universitas Pendidikan Ganesha.

Nicholson, Walter. (2008). Teori Mikro Ekonomi, Edisi 5. Jakarta: Binarupa Aksara.

Qanun Aceh Tahun 2013 Nomor 11 Tentang Kesejahteraan Sosial

Risyanti Riza, H. Roesmidi. (2006). Pemberdayaan Mayarakat. Sumedang. Jatinangor: Al qaprint.

Samuelson, Paul A. dan William D. Nordhaus. (2001). Economics. Eighteenth Edition, Mc. Graw Hill Company. Irwin.

Sukirno, Sadono. (2013). Ekonomi Makro. Jakarta: Raja Grafindo Persada.

Todaro, Michael P. dan Stephen C. Smith. (2006). Pembangunan Ekonomi. Edisi Kesembilan. Jilid I. Jakarta: Erlangga.
Winardi. (2010). Ekonomi pembangunan. Jakarta: Gramedia.

Wirutomo, Paulus. (2012). Sistem Sosial Indonesia. Jakarta: Universitas Indonesia.
- How to cite this paper :

Ulfia \& Rahmi. (2018). Analisis Kehidupan Sosial Ekonomi Pengemis dan Penanggulangannya di Kota Banda Aceh.. Jurnal Humaniora, 2(2), 130-139. 